\section{Seedling Emergence and Yield from Hydrated Collard Seeds Fluid-drilled in High-phosphorus Gel}

\author{
Wallace G. Pill \\ Delaware Agricultural Experiment Station, Department of Plant and Soil \\ Sciences, College of Agricultural Sciences, University of Delaware, \\ Newark, DE 19717-1303 \\ Additional index words. Brassica oleracea var. acephala, cole crop, crucifer, \\ Cruciferae, seed treatment
}

\begin{abstract}
Seeds of 'Champion' collard (Brassica oleracea L. var. acephala) were hydrated in water or a fluid-drilling gel ( $\mathrm{N}$-gel, hydroxyethyl cellulose) for 1 or 2 days at $20 \mathrm{C}(50 \mathrm{seeds} / \mathrm{ml})$ before they were fluid-drilled into peat-lite in a greenhouse. Time to $50 \%$ seedling emergence from these seeds was more than 2 days earlier than from dry-sown untreated seeds, although emergence synchrony and percentage were unaffected. A second greenhouse study revealed more rapid seedling emergence from hydrated seeds that then were fluid-drilled than from dry-sown untreated seeds even

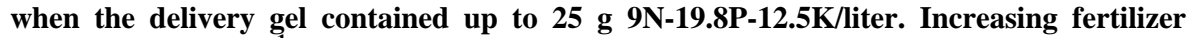
from 5 to 25 g.liter ${ }^{-1}$ led to increased shoot fresh weight 6 weeks after planting. When sown on two dates into field plots, hydrated seeds (1 day in either water or gel at 20C, 50 seeds/ml) that were fluid-drilled in $1.5 \%$ (w/v) N-gel containing 5 or $15 \mathrm{~g}$ 9N-19.8P12.5K/liter yielded $42 \%$ greater final shoot fresh weights than untreated seeds sown dry.
\end{abstract}

Efficient production of high yields of fieldgrown vegetable crops requires the rapid establishment of a full stand of seedlings. This desirable goal often is not achieved because of poor seed-lot quality and/or the difficulty of preparing and maintaining good seed-bed conditions. Seedling emergence of collard, as with most cole crops, can be rapid and uniform when conditions are conducive to stand establishment. However, stands frequently can be poor and unpredictable largely as a result of adverse environmental conditions after sowing. Increased mechanical impedance resulting from soil settling, soil crusting, or the action of the seed drill press wheel also can reduce crop stands (Royle and Hegarty, 1977).

Fluid drilling (gel seeding) is a planting method that includes the sowing of germinated seeds in a protective carrier (Gray, 1984). This technique can give earlier, greater, and more uniform seedling emergence; earlier and higher yields; and in some crops, more uniform maturity than conventional methods of sowing untreated seeds (Gray, 1984). The need for specialized equipment, the sophistication of the technique, and variable responses to fluid drilling, however, have contributed to its low commercial acceptance. 'I-his variability can result

Received for publication 20 Feb. 1990. Published as Miscellaneous Paper 1305 of the Delaware Agricultural Experiment Station. Mention of trade names in this publication does not imply endorsement by the Delaware Agricultural Experiment Station of the products named, nor criticism of similar ones nor mentioned. Contribution 259 of the Plant and Soil Science Dept. The cost of publishing this paper was defrayed in part by the payment of page charges. Under postal regulations, this paper therefore must be hereby marked advertisement solely to indicate this fact. from the low proportion of germinated seeds in a germinating seed lot at the time of fluid drilling (Finch-Savage, 1987; Pill and FinchSavage, 1988) and IO the strong interaction of the germinated seeds with the seed-bed environment (Finch-Savage, 1987; Finch-Savage and Pill, 1990). The success of a commercial grower in fluid-drilling untreated collard seeds over Iwo growing seasons (Pill, 1990) prompted Iwo greenhouse studies and a field study reported herein that examined the responses of fluid-drilled collard seeds to seed hydration treatments and the incorporation of high-P fertilizer in the carrier gel.

The seed hydration treatments for the first greenhouse experiment (Table 1) were conducted by placing 50 seeds and $1 \mathrm{ml}$ of demineralized water, gel, or polyethylene glycol (PEG 8000) within a $26 \times 33-\mathrm{mm}$ well of an eight-well tissue culture plate (Miles Scientific, Naperville, Ill.). Each plate, after securing the lid, was placed within a plastic bag before exposure to the appropriate temperature. The gel used to hydrate and fluiddrill the seeds was $1.5 \%$ (w/v) hydroxyethyl (Greenhouse Expt. 1).

\footnotetext{
***Treatments significant at $\mathrm{P} \leq 0.01$.
}

cellulose (N-gel; Aqualon Group, Wilmington, Del.; see Banyai, 1987). Seeds were soaked for 7 days at $5 \mathrm{C}$ in either water [treatment (tt) 1] or gel (tt 2). Seeds of tt 3 were osmotically primed at $20 \mathrm{C}$ for 7 days in -1.2 MPa PEG (314 g PEG/liter of water; Michel and Kaufman, 1973). Other 50-seed samples were soaked for 2 days in $20 \mathrm{C}$ gel (tt 4 ), for 1 day in 20C gel (tt 5), or for 1 day in 20C water then 1 day in gel at $20 \mathrm{C}$ (tt 6). Treatment 7 was untreated seeds mixed with gel at the time of fluid drilling, and $\mathrm{tt} 8$ was untreated seeds that were sown dry.

Seeds from tts 1 through 7 were mixed in $1.5 \mathrm{ml}$ of $\mathrm{N}$-gel contained within a $125-\mathrm{ml}$ plastic bag. The gel-seed mixtures were extruded into five 1 -cm-deep $\times 12$-cm-long furrows in $17 \times 12 \times 6-\mathrm{cm}$ plastic flats containing peat-lite (Redi-Earth; W.R. Grace and Co., Cambridge, Mass.). The untreated seeds (tt 8) were sown by hand. The seeded furrows were covered with $1 \mathrm{~cm}$ of peat-lite. The flats were surface-irrigated daily but were not fertilized.

The eight treatments (flats) were replicated five times in a randomized completeblock design. The study was conducted in a greenhouse under natural light (Mar.-Apr. 1989) with day/night ranges of 15 to $32 \mathrm{C} / 9$ to $17 \mathrm{C}$. The number of seedlings emerged (hypocotyls first visible) were recorded daily until emergence was complete. From these data, days to $50 \%$ emergence $\left(\mathrm{E}_{50}\right)$, days between $10 \%$ and $90 \%$ emergence $\left(E_{10-90}\right)$, and the angular transformation of final percent emergence were calculated. These variables were subjected to analysis of variance.

Based on the results of the first experiment, the seed hydration treatments selected for the second greenhouse study were 1- or 2-day soaks in 20C water or 20C gel. Seeds of these treatments and untreated seeds were fluid-drilled in gel containing $0,5,15$, or 25 g 9N-19.8P-12.5K (Peters 9-45-15 Plant Starter; W.R. Grace and Co., Fogelville, Pa.). The gel-seed mixtures were extruded into seed-bed furrows in peat-lite contained in plastic flats as described for the first greenhouse experiment. The 5 (seed treatment) $\times$ 4 (fertilizer rate) factorial (plus a dry-sown untreated seed control) was arranged in a randomized complete-block design with five replications. The study was conducted under natural light (Apr.-May 1989) with day/night ranges of 24 to $32 \mathrm{C} / 11$ to $19 \mathrm{C}$. The flats were surface-irrigated daily and received no

Table 1. Days to $50 \%$ emergence of 'Champion' collard seedlings as a result of seed treatments

\begin{tabular}{|c|c|c|}
\hline $\begin{array}{l}\text { Seed } \\
\text { treatment no. }\end{array}$ & $\begin{array}{l}\text { Treatment } \\
\text { description }\end{array}$ & $\begin{array}{c}\text { Days to } 50 \% \\
\text { emergcnce }\left(E_{90}\right)\end{array}$ \\
\hline 1 & 7 Days in $5 C$ water & 4.1 \\
\hline 2 & 7 Days in $5 \mathrm{C} \mathrm{gel}$ & 3.8 \\
\hline 3 & 7 Days in $200^{\circ}$ PEG & 4.6 \\
\hline 4 & 2 Days in $20 \mathrm{Cgel}$ & 3.6 \\
\hline 5 & 1 Day in $20 \mathrm{C}$ gel & 3.7 \\
\hline \multirow[t]{2}{*}{6} & 1 Day in $20 \mathrm{C}$ water & \\
\hline & then 1 day in $20 \mathrm{Cgc}$ & 3.5 \\
\hline 7 & Untreated (fluid-drilled) & 5.3 \\
\hline 8 & Untreatcd (sown dry) & 5.9 \\
\hline $1 S D_{0, n s}$ & & $0.24^{\cdots}$ \\
\hline
\end{tabular}


Table 2. Emergence characteristics of 'Champion' collards as a result of seed treatment and fertilizer addition to the fluid-drilling gel (Greenhouse Expt. 2).

\begin{tabular}{|c|c|c|c|}
\hline $\begin{array}{l}\text { Seed } \\
\text { treatment }\end{array}$ & $\begin{array}{c}9 \mathrm{~N}-19.8 \mathrm{P}-12.5 \mathrm{~K} \\
\text { in } \mathrm{gel} \\
(\mathrm{g} \cdot \mathrm{litcr}-1)\end{array}$ & $\begin{array}{c}\text { Days to } 50 \% \\
\text { emergence } \\
\left(E_{9 n}\right)\end{array}$ & $\begin{array}{c}\text { Days berween } 10 \% \\
\text { and } 90 \% \text { emergence } \\
\left(\mathrm{E}_{10-\infty \mathrm{n}}\right)\end{array}$ \\
\hline \multicolumn{4}{|l|}{2 Days } \\
\hline \multirow[t]{4}{*}{ in water } & 0 & 3.5 & 2.1 \\
\hline & 5 & 3.8 & 2.7 \\
\hline & 15 & 4.0 & 3.2 \\
\hline & 25 & 4.5 & 3.6 \\
\hline \multicolumn{4}{|l|}{2 Days } \\
\hline \multirow[t]{4}{*}{ in gel } & 0 & 3.6 & 1.7 \\
\hline & 5 & 3.7 & 2.0 \\
\hline & 15 & 3.6 & 2.5 \\
\hline & 25 & 4.0 & 3.8 \\
\hline \multicolumn{4}{|l|}{1 Day } \\
\hline \multirow[t]{4}{*}{ in water } & 0 & 3.7 & 1.8 \\
\hline & 5 & 3.6 & 1.5 \\
\hline & 15 & 3.9 & 1.9 \\
\hline & 25 & 4.1 & 2.4 \\
\hline \multicolumn{4}{|l|}{ I Day } \\
\hline \multirow[t]{4}{*}{ in $\mathrm{gcl}$} & 0 & 3.7 & 1.7 \\
\hline & 5 & 3.7 & 1.6 \\
\hline & 15 & 3.7 & 1.7 \\
\hline & 25 & 3.7 & 1.8 \\
\hline \multicolumn{4}{|l|}{ Untreated } \\
\hline \multirow[t]{4}{*}{ (fluid-drilled) } & 0 & 4.6 & 2.2 \\
\hline & 5 & 4.5 & 2.2 \\
\hline & 15 & 4.7 & 1.7 \\
\hline & 25 & 4.6 & 1.8 \\
\hline Intcraction $\mathrm{LSD}_{n}$. & & 0.22 & 0.51 \\
\hline \multirow{2}{*}{\multicolumn{4}{|c|}{$\begin{array}{l}\text { Sum of squarcs and } \\
F \text { icst significances }\end{array}$}} \\
\hline & & & \\
\hline Seed trealment (S) & & $8.76^{\circ *}$ & $16.58^{* \bullet}$ \\
\hline Fertilizer rate $(F)$ & & $1.47^{* *}$ & $7.42=*$ \\
\hline$S \times F$ & & $1.48 * *$ & $10.09 * *$ \\
\hline
\end{tabular}

${ }^{\mathrm{z}}$ For untreated seeds sown dry, $\mathrm{E}_{50}$ was 5.0 days and $\mathrm{E}_{10-90}$ was 1.7 days.

**Significant at $P \leq 0.01$

Table 3. Influence of seed treatment and fertilizer concentration in gel on shoot fresh weight of 'Champion' collards 2 and 6 weeks after fluid drilling (Greenhousc Expt. 2).

\begin{tabular}{|c|c|c|}
\hline \multirow[b]{3}{*}{ Treatments } & \multicolumn{2}{|c|}{$\begin{array}{c}\text { Shoot fresh wt } \\
\text { (mg/shoot) }\end{array}$} \\
\hline & \multicolumn{2}{|c|}{$\begin{array}{l}\begin{array}{l}\text { Time after planting } \\
\text { (weeks) }\end{array} \\
\end{array}$} \\
\hline & 2 & 6 \\
\hline \multicolumn{3}{|l|}{ Seed ircatment } \\
\hline 2 Days in water & 21.0 & 260 \\
\hline 2 Days in $\mathrm{gcl}$ & 23.7 & 313 \\
\hline l Day in watcr & 22.6 & 286 \\
\hline 1 Day in gel & 24.2 & 367 \\
\hline Untreated (fluid-drilled) & 20.5 & 293 \\
\hline $\operatorname{LSD}_{0.11}$ & 1.6 & 14 \\
\hline \multicolumn{3}{|c|}{$9 \mathrm{~N}-19.8 \mathrm{P}-12.5 \mathrm{~K}$ in $\mathrm{gel}\left(\mathrm{g} \cdot\right.$ liter $\left.^{-1}\right)$} \\
\hline 0 & 21.6 & 193 \\
\hline 5 & 22.6 & 198 \\
\hline 15 & 22.5 & 364 \\
\hline 25 & 22.9 & 460 \\
\hline \multicolumn{3}{|l|}{ Sum of squares and } \\
\hline$F$ test significances & & \\
\hline $\begin{array}{l}\text { Seed treatment (S) } \\
\text { Fertilizer rate (F) }\end{array}$ & $166^{* *}$ & $103,139^{\cdots *}$ \\
\hline Linear & $14^{\text {NS }}$ & $940,641 \cdots$ \\
\hline Quadratic & $2^{\mathrm{NS}}$ & $41,390^{*}$ \\
\hline Cubic & $2^{\text {NS }}$ & $53,948 * \cdots$ \\
\hline$S \times F$ & $35^{\mathrm{NS}}$ & $8.458^{\mathrm{NS}}$ \\
\hline
\end{tabular}

${ }^{\mathrm{z}}$ Shoot fresh weights from untreated seeds sown dry were 18.8 and $155 \mathrm{mg}$ at 2 and 6 weeks, respectively, after sowing.

NS ${ }^{* * N}$ Not significant or significant at $P \leq 0.01$, rcspectively. shoot fresh weight of each removed plant was recorded. Four weeks after each planting date, the plots were sidedressed with $33 \mathrm{~N}$ $\mathrm{OP}-0 \mathrm{~K}$ at $35 \mathrm{~kg} \mathrm{~N} / \mathrm{ha}$. Soil moisture was maintained at adequate levels by sprinkler irrigation when no rain fell. The shoots of the central $2 \mathrm{~m}$ of each row were harvested and fresh weights recorded 7 weeks and 9 weeks after the first and second plantings, respectively.

Greenhouse Expt. 1. Seed treatments influenced $\mathrm{E}_{50}$ significantly (Table 1) but had no effect on percent seedling emergence or on $\mathrm{E}_{10-90}$, which averaged $93 \%$ and 1.8 days, respectively (data not shown). All seed treatments advanced emergence compared to that of untreated (dry) seeds. By reducing the time from sowing to seedling emergence, such treatments could lessen exposure IO adverse factors such as seed bed mechanical impedance, which usually increases from the time of sowing (Hegarty, 1978). Hydrating the seeds at 20C in water then gel (1 day in each, tt 6 ) or 1 or 2 days in gel (tts 5 and 4) advanced time to $50 \%$ emergence by more than 2 days relative to untreated seeds that were dry-sown (tt 8). Exceeding 2 days of soaking in either gel or water at $20 \mathrm{C}$ resulted in radicle emergence before sowing (data not shown).

Osmotic priming (tt 3) or cold treatment of the seeds (tts 1 and 2) was no more beneficial than the hydration treatments in advancing seedling emergence. Seedling emergence from osmotically primed seeds may be. improved by selecting an optimum combination of priming conditions, such as osmoticum, osmotic potential, and the temperature and duration of exposure (Evans and Pill, 1989). Likewise, reducing the temperature and extending the period of cold exposure could improve seed response to the cold treatment (Finch-Savage and Cox, 1982b). Extending the water soak at 20C to 2 or 3 days before the exposure to cold resulted in radicle emergence (data not shown).

Greenhouse Expt. 2. Seed treatment interacted significantly with concentration of $9 \mathrm{~N}-19.8 \mathrm{P}-12.5 \mathrm{~K}$ in the fluid-drilling gel in influencing $\mathrm{E}_{50}$ and $\mathrm{E}_{10-90}$ (Table 2). $\mathrm{E}_{10-90}$ values generally varied in parallel with $E_{50}$ values so that delayed emergence was associated with less synchronous emergence. Percent emergence was unaffected by treatments but averaged 92\%. Seedling emergence from seeds hydrated for 1 or 2 days was more rapid than from untreated seeds that were fluid-drilled, which, in turn, emerged earlier than untreated seeds sown dry. The average 1.2-day advancement in $\mathrm{E}_{50}$ from seeds hydrated for 1 day before fluid drilling compared to untreated seeds sown dry represents the time following sowing necessary for seed imbibition by untreated seeds that can be avoided by fluid drilling hydrated seeds. Increasing fertilizer concentration in the gel from 0 to $25 \mathrm{~g} \cdot$ liter $^{-1}$ delayed emergence, except when untreated seeds or seeds hydrated for 1 day in gel were fluid-drilled. Delayed emergence of seedlings with high fertilizer concentration in the fluid-drilling gel has been reported (FinchSavage and Cox, 1982a) and has been as- 
Table 4. Early and final shoot fresh weights of 'Champion' collards as influenced by seed treatment and fertilizer addition to the fluid-drilling gel following two sowing dates (15 June and 12 July 1989) in field plots.

\begin{tabular}{|c|c|c|c|c|c|}
\hline \multirow[b]{3}{*}{$\begin{array}{l}\text { Seed } \\
\text { treatment }\end{array}$} & \multirow[b]{3}{*}{$\begin{array}{c}9 \mathrm{~N}-19.8 \mathrm{P}-12.5 \mathrm{~K} \text { in } \mathrm{gcl} \\
\left(\mathrm{g} \cdot \mathrm{litcr}^{-1}\right)\end{array}$} & \multicolumn{4}{|c|}{ Shoot fresh wit } \\
\hline & & \multicolumn{2}{|c|}{ Sowing 1} & \multicolumn{2}{|c|}{ Sowing 2} \\
\hline & & $\begin{array}{c}\text { Early } \\
\text { (mg/shoot) }\end{array}$ & $\begin{array}{c}\text { Final } \\
(\mathrm{g} / \text { shoot })\end{array}$ & $\begin{array}{c}\text { Early } \\
\text { (mg/shoot) }\end{array}$ & $\begin{array}{c}\text { Final } \\
(\mathrm{g} / \text { shoot })\end{array}$ \\
\hline $\begin{array}{l}1 \text { Day } \\
\text { in gel }\end{array}$ & $\begin{array}{r}0 \\
5 \\
15\end{array}$ & $\begin{array}{l}122 \\
164 \\
173\end{array}$ & $\begin{array}{l}209 \\
236 \\
282\end{array}$ & $\begin{array}{l}573 \\
530 \\
631\end{array}$ & $\begin{array}{l}234 \\
225 \\
238\end{array}$ \\
\hline $\begin{array}{l}1 \text { Day } \\
\text { in water }\end{array}$ & $\begin{array}{r}0 \\
5 \\
15\end{array}$ & $\begin{array}{l}151 \\
176 \\
184\end{array}$ & $\begin{array}{l}212 \\
254 \\
254\end{array}$ & $\begin{array}{l}479 \\
556 \\
683\end{array}$ & $\begin{array}{l}211 \\
239 \\
267\end{array}$ \\
\hline $\begin{array}{l}\text { Untreated } \\
\text { (fluid-drilled) }\end{array}$ & $\begin{array}{r}0 \\
5 \\
15\end{array}$ & $\begin{array}{l}117 \\
172 \\
190\end{array}$ & $\begin{array}{l}192 \\
257 \\
356\end{array}$ & $\begin{array}{l}431 \\
434 \\
676\end{array}$ & $\begin{array}{l}195 \\
181 \\
190\end{array}$ \\
\hline $\begin{array}{l}\text { Untreated } \\
\text { (sown dry) }\end{array}$ & $\ldots$ & 121 & 180 & 340 & 171 \\
\hline $\begin{array}{l}\mathrm{LD}_{0.0 \mathrm{~s}^{\mathrm{y}}} \\
\text { Sum of squares and } \\
\mathrm{F} \text { test significances } \\
\text { Seed treatment }(\mathrm{S}) \\
\text { Fertilizer rate }(\mathrm{F}) \\
\mathrm{S} \times \mathrm{F}\end{array}$ & & $\begin{array}{c}1,428^{\mathrm{NS}} \\
15,053^{*} \\
2,329^{\mathrm{NS}}\end{array}$ & $\begin{array}{r}68,161^{\mathrm{NS}} \\
512,723^{* *} \\
154,015^{\mathrm{NS}}\end{array}$ & $\begin{array}{c}30,358^{\mathrm{Ns}} \\
212,767^{*} \\
50,567^{\mathrm{Ns}}\end{array}$ & $\begin{array}{r}501,471^{* *} \\
72,621^{\mathrm{Ns}} \\
140,746^{\mathrm{NS}}\end{array}$ \\
\hline
\end{tabular}

${ }^{\mathrm{z}}$ Early and final harvests, respectively, were 28 June and 2 Aug. (sowing 1) and 2 Aug. and 19 Sept. (sowing 2).

${ }^{\mathrm{y}} \mathrm{LSD}_{0.05}$ for all treatments (One-Way analyses).

${ }^{\mathrm{x}} \mathrm{F}$ tests for one-way analyses significant at $P \leq 0.05$ or $P \leq 0.01\left({ }^{* *}\right)$ or nonsignificant $\left({ }^{\mathrm{NS}}\right)$.

sociated with high gel electrical conductivity (Espinosa and Pill, 1987). The high fertilizer concentration may osmotically induce water stress around the seeds during their short exposure $(\leq 1 \mathrm{~h})$ to the fertilizer. After sowing, I observed that $\mathrm{N}$-gel quickly diffused away from the seed in the seed bed so that osmotic stress from the fertilizer following delivery was unlikely.

Shoot fresh weights 2 weeks after sowing (Table 3) generally were inversely related to seed treatment effects on $\mathrm{E}_{50}$, as already reported for other species (Evans and Pill, 1989; Pill, 1986). Seeds hydrated in gel for 1 or 2 days or in water for 1 day gave greater shoot fresh weights 2 weeks after sowing than untreated seeds or seed soaked in water for 2 days. All fluiddrilled seeds gave greater shoot fresh weights 2 weeks after sowing than untreated seeds that were sown dry. Fertilizer inherently present in the commercial peatlite may have masked the effect of $9 \mathrm{~N}-19.8 \mathrm{P}-$ $12.5 \mathrm{~K}$ in the fluid-drilling gel so that this treatment had no effect on shoot fresh weights 2 weeks after sowing. By 6 weeks after sowing, however, early differences in shoot fresh weight due to seed treatments were retained, but, additionally, increasing fertilizer concentration in the gel significantly increased shoot fresh weights. The highest fertilizer rate $\left(25 \mathrm{mg} \cdot \operatorname{liter}^{-1}\right)$ gave shoot fresh weights $197 \%$ higher than the $155 \mathrm{mg} / \mathrm{shoot}$ from untreated dry-sown seeds. Presumably, available $P$ in the peat-lite had reached deficient levels by 6 weeks after sowing. Espinosa and Pill (1987) reported that while increasing $\mathrm{P}$ concentration in the gel did not affect seedling shoot dry weight of fluiddrilled tomato in high-P media, it increased both shoot fresh weight and shoot $\mathrm{P}$ concentration in low-P media.
Field experiment. Early shoot fresh weights from both sowing dates were influenced only by fertilizer concentration in the fluid-drilling gel (Table 4). Thus. seed treatment effects that were apparent under greenhouse conditions were not observed under field conditions. Earlier emergence and increased seedling growth from primed (Pill and FinchSavage, 1988) or from hydrated seeds (Bennett and Waters, 1987) relative to untreated seeds is more pronounced in colder environments. Earlier plantings during April and May, when soils were cooler, were flooded by rainfalls totalling $95 \mathrm{~mm}$ above normal. Mean air temperature (1.8 m above ground) was 23.1 and $22.5 \mathrm{C}$ for 3 weeks following sowing dates 1 and 2, respectively. Thus, high soil temperatures masked differences in seedling emergence rare due to seed treatment.

Even though the field plots had received preplant fertilizer at recommended rates, shoot growth was increased by the small amount of fertilizer in the gel, in agreement with the results of Finch-Savage and Cox (1982a) for carrots, Seedlings can use only phosphate that is present in the small volume of soil occupied by their roots. since $\mathrm{P}$ movement is negligible in soil. Treatment-induced differences in shoot growth 2 weeks after the first sowing were retained so that 4.5 weeks later, at final harvest. fertilizer in the gel increased shoot fresh weights. The highest fertilizer rate $\left(15 \mathrm{~g} \cdot\right.$ liter $\left.^{-1}\right)$ increased shoot fresh weight from the first sowing an average of $65 \%$ over that of untreated seeds that were sown dry. There is evidence (Knoll et al., 1964) that a larger effect of the placed $P$ would be expected at lower temperatures than experienced in the present study.

While early shoot fresh weights from sow- ing 2 were significantly influenced only by fertilizer concentration in the gel, only seed treatment influenced shoot weights at the final harvest (Table 4). Shoot fresh weights from seeds hydrated in waler or gel for 1 day were $35 \%$ or $38 \%$ greater than those from untreated seeds that were fluid-drilled or sown dry, respectively. Compared to conventional sowing, fluid-drilling germinated seeds gave inferior stands of fall-harvested broccoli and cauliflower crops (Kahn and Motes, 1988; 1989) when air temperatures at and following planting exceeded 30C. These results likely may be attributed to heat and desiccation. Seed-bed conditions for germinated or germinating seeds that are fluid-drilled must be conducive to continued seedling growth since germinated seeds become desiccation intolerant (Finch-Savage, 1987). Hydrated but nongerminated seeds that have been fluiddrilled into an adverse seed-bed environment may remain quiescent until conditions suitable for radicle protrusion arise.

Since mechanical crust disruption led to a 2- to 3-fold increase in rapeseed seedling establishment (Morrison et al., 1988), it is likely that anticrustant materials also would be beneficial to collard stand establishment. When deposited shallowly $(<15 \mathrm{~mm})$, the fluid-drilling gel may act as a soil anticrustan:. Page and Quick (1979) found hydroxyethyl cellulose (Natrosol 350 HHR; Aqualon), which is chemically similar to N-gel, to be the most effective of several organic soil conditioners, including polyvinyl alcohol, in reducing crust strength.

The results of these studies reveal that fluid drilling of hydrated seeds in a gel fortified with high-P fertilizer can improve shoot yield of collards. Incorporation of high-P "starter" fertilizer in the gel provided a low-input op- 
tion to place $\mathrm{P}$ near the seedling root system. Further work is required, however, to examine the germination responses following seed hydration within large volumes of gel. The gel may act as a priming agent as the hydrating seeds remove water from the gel matrix, causing the gel water potential to decrease. Seedling emergence responses of hydrated seeds fluid-drilled into soils of varying water availability, temperature, and crust potential likewise require exploration.

\section{Literature Cited}

Banyai, B.E. 1987. N-gel ${ }^{\text {TM }}$ polymers for agricultural fluid-drilling. Acta Hort. 198:111-120.

Bennett, M.A. and L. Waters. 1987. Germination and emergence of high-sugar sweet corn is improved by presowing hydration of seed. HortScience 22:236-238.

Espinosa, W.A. and W.G. Pill. 1987. Response of tomato seeds fluid-drilled in low-phosphorus growth media to phosphorus incorporation in the carrier gel. Scientia Hort. 33:37-47.

Evans, T.A. and W.G. Pill. 1989. Emergence and seedling growth from osmotically primed or pregerminated seeds of asparagus (Asparagus officinalis L.). J. Hort. Sci. 64:275-282.

Finch-Savage, W.E. 1987. The potential for seed, sowing and seedbed preparation treatments to improve the production of uniformly-sized carrot roots for processing. Acta Hort. 220:181188.

Finch-Savage, W.E. and C.J. Cox. 1982a. Effects of adding plant nutrients to the gel carrier used for fluid drilling early carrots. J. Agr. Sci. 99:295-303.

Finch-Savage, W.E. and C.J. Cox. 1982b. A coldtreatment technique to improve the germination of vegetable seeds prior to fluid drilling. Scientia Hort. 16:301-311.

Finch-Savage, W.E. and W.G. Pill. 1990. Improvement of carrot crop establishment by combining seed treatments with increased seed-bed moisture availability. J. Agr. Sci. 115:75-81.

Gray, D. 1984. The role of fluid drilling in plant establishment. Aspects Appl. Biol. 7:153-171.

Hegarty, T.W. 1978. Seed and sod factors affecting the level and rate of emergence. Acta Hort. 72: 11-25.

Kahn, B.A. and J.E. Motes. 1988. Comparison of fluid drilling with conventional planting methods for stand establishment and yield of spring and fall broccoli crops. J. Amer. Soc. Hort. Sci. 113:670-674

Kahn, B.A. and J.E. Motes. 1989. Comparison of fluid drilling with conventional planting methods for stand establishment and yield of spring and fall cauliflower crops. J. Amer. Soc. Hort. Sci. 114:200-204.

Knoll, H.A., N.C. Brady, and D.J. Lathwell. 1964. Effect of soil temperature and phosphorus fertilization on the growth and phosphorus content of corn. Agron. J. 56:145-147.

Michel, B.E. and M.R. Kaufmann. 1973. The osmotic potential of polyethylene glycol 6000. Plant Physiol. 51:914-916.

Morrison, L.N., R. Khan, and A. Rashid. 1988. Effects of seeding methods and soil crusting on establishment of rapeseed (Brassica napus) and mustard (B. juncea). Field Crops Res. 19:2739.

Page, R.E. and M.J. Quick. 1979. A comparison of the effectiveness of organic polymers as soil anti-crusting agents. J. Sci. Food Agr. 30:112118

Pill. W.G. 1986. Parsley emergence and seedling growth from raw. osmoconditioned and pregerminated seeds. HortScience 21:1134-1136.
Pill, W.G. 1990. Gel seeding makes cole crop comeback. Amer. Veg. Grower 38:29, 32-33.

Pill, W.G. and W.E. Finch-Savage. 1988. Effects of combining priming and plant growth regulater treatments on the synchronisation of carrot seed germination. Ann. Appl. Biol. 113:383389.

Royle. S.M. and T.W. Hegarty. 1977. Soil impedance and field cmergence in calabrese. J. Hort. Sci. 52:535-543. 